\title{
PENGARUH EDUKASI MELALUI WEBINAR TERHADAP TINGKAT PENGETAHUAN TENTANG NAPZA DAN GIZI BAGI REMAJA
}

\author{
Riezky Faisal Nugroho ${ }^{1 *}$, Erika Martining Wardani \\ ${ }^{1}$ Poltekkes Kemenkes Surabaya, Indonesia \\ ${ }^{2}$ Universitas Nahdlatul Ulama Surabaya, Indonesia \\ Email : riifan7@gmail.com
}

\begin{abstract}
Abstrak
Remaja merupakan masa yang kritis saat untuk berjuang melepaskan ketergantungan kepada orang tua dan usaha mencapai kemandirian sehingga dapat diterima dan diakui sebagai orang dewasa. Pengetahuan remaja tentang Napza akan menghindarkan remaja dari penyalahgunaan Napza serta konsumsi gizi yang seimbang akan berpengaruh pada pertumbuhan dan perkembangannya. Masalah gizi remaja juga perlu mendapatkan perhatian. Edukasi yang tepat untuk masa pandemi salah satunya dengan webinar. Tujuan penelitian untuk mengetahui pengaruh edukasi melalui webinar terhadap tingkat pengetahuan tentang Napza dan gizi bagi remaja. Penelitian ini adalah penelitian quasy eksperimental, populasi dalam penelitian ini sebanyak 113 responden dengan jumlah sampel 88 responden. Teknik pengambilan sampel dengan simple random sampling. Instrumen penelitian dengan kuesioner melalui google form. Data dianalisis dengan wilcoxon test. Hasil penelitian menunjukan bahwa setelah mendapatkan edukasi dengan webinar terdapat peningkatan pengetahuan tentang Napza $(p$ value $=0,001)$ dan gizi $(p$ value $=0,000)$. Edukasi melalui webinar sangat efektif dilakukan untuk meningkatkan pengetahuan tentang Napza dan gizi bagi remaja. Perlu diberikan edukasi secara berkala guna meningkatkan pengetahuan terutama Napza dan gizi sehingga remaja dapat hidup
\end{abstract}

Kata kunci: edukasi; webinar; pengetahuan; Napza; gizi

\begin{abstract}
Adolescence is a critical period when struggling to release dependence on parents and efforts to achieve independence so that they can be accepted and recognized as adults. Adolescent knowledge about drugs will prevent adolescents from drug abuse and consumption of balanced nutrition will affect their growth and development. The nutritional problems of adolescents also need attention. The right education for the pandemic period is one of them with webinars. The purpose of the study was to determine the effect of education through webinars on the level of knowledge about drugs and nutrition for adolescents. This study is a quasi-experimental study, the population in this study was 113 respondents with a sample of 88 respondents. The sampling technique was simple random sampling. The research instrument is a questionnaire via google form. Data were analyzed by Wilcoxon test. The results showed that after receiving education with the webinar there was an increase in knowledge about drugs ( $p$ value $=0.001)$ and nutrition $(p$ value $=0.000)$. Education through webinars is very effective to increase knowledge about drugs and nutrition for teenagers. Periodic education needs to be given to increase knowledge, especially drugs and nutrition so that teenagers can live healthy lives.
\end{abstract}

Keywords: education; webinars; knowledge; Napza; nutrition 


\section{Pendahuluan}

Masa remaja merupakan masa yang kritis, yaitu saat untuk berjuang melepaskan ketergantungan kepada orang tua dan berusaha mencapai kemandirian sehingga dapat diterima dan diakui sebagai orang dewasa. Keberhasilan remaja melalui massa transisi ini dipengaruhi oleh faktor individu (biologi, kognitif, psikologis) dan lingkungan (keluarga, teman sebaya, masyarakat). Keinginannya cenderung melakukan jalan pintas dalam menghadapi masalah, tidak memiliki keyakinan diri yang mantap, menjadi pengikut yang tidak berdaya, mengelak dari tugas dan tanggung jawab serta hanya menuntut hak (Iskandar, 2017).

Angka kejadian penyalahgunaan Napza dunia tahun 2014 adalah antara 162 juta hingga 324 juta orang atau sekitar 3,5-7\% (UNOCD, 2016). Angka kejadian penyalahgunaan Napza di Indonesia setiap tahun selalu meningkat. Tahun 2014 sebesar 2,18 \% dan pada tahun 2016 sebesar 2,21 \% (BNN RI, 2016). Angka kejadian penyalahgunaan Napza di Jawa Timur pada tahun 2016 sebesar $2 \%$ atau 636.00 jiwa (BNN Jawa Timur, 2016). Angka penyalahgunaan Napza di Kota Surabaya sebesar $0,012 \%$ sedangkan pelajar yang menyalahgunakan Napza di Kota Surabaya sebesar $0,0064 \%$. Berdasarkan data didapatkan data bahwa terdapat 359 penyalahguna Napza dari berbagai kelompok usia terdapat 189 pelajar yang terlibat penyalahgunaan Napza (BNN Kota Surabaya, 2015). Jumlah pelajar SMA penyalahgunaan Napza (0.0027\%). Pelajar SMP sebanyak $(0,0025 \%)$ dan pelajar SD sebanyak $(0,0012 \%)$ (Polrestasbes Surabaya, 2016).

Permasalahan kesehatan dan gizi remaja akan memengaruhi kualitas hidupnya pada usia produktif dan usia selanjutnya. Masalah gizi (baik gizi kurang maupun gizi lebih) dapat meningkatkan kerentanan terhadap penyakit, khususnya risiko terjadinya penyakit tidak menular. Berdasarkan data Riskesdas diperoleh 25,7\% remaja usia 13-15 tahun dan 26,9\% remaja usia 16-18 tahun dengan status gizi pendek dan sangat pendek. Kemudian data menunjukkan bahwa 8,7\% remaja usia $13-15$ tahun dan 8,1\% remaja usia 16-18 tahun memiliki kondisi kurus dan sangat kurus. Sedangkan prevalensi obesitas sebesar $16,0 \%$ pada remaja usia 13-15 tahun dan 13,5\% pada remaja 16-18 tahun (Riskesdas, 2018)

Penyalahgunaan Napza pada remaja bukan suatu peristiwa yang timbul karena suatu pemicu melainkan akibat dari beberapa sebab yang merupakan faktor pendorong sehingga dapat meningkatkan resiko remaja dalam menyalahgunakan Napza (Setiawan, 2015). Salah satu akibat dari penyalahgunaan Napza yaitu menyerang fungsi otak yang dapat mengakibatkan daya ingat menurun, sulit benkonsentrasi, menimbulkan perasaan khayal dan kemampuan belajar merosot (BNN RI, 2016). Keadaan seperti itulah yang menyebabkan pelajar bermalas-malasan sehingga prestasi belajar akan menurun. Pelajar merupakan generasi penerus bangsa. Penyalahgunaan Napza pada pelajar dapat merusak satu generasi yang akan berdampak pada hilangnya satu generasi kepemimpinan (Setiawan, 2015). 
Permasalahan yang terjadi pada remaja selain napza adalah asupan nutrisi yang mempengaruhi status gizi remaja. Sebagian besar remaja menggunakan waktu luang mereka untuk kegiatan tidak aktif, sepertiga remaja makan cemilan buatan pabrik atau makanan olahan, sedangkan sepertiga lainnya rutin mengonsumsi kue basah, roti basah, gorengan, dan kerupuk. Perubahan gaya hidup juga terjadi dengan semakin terhubungnya remaja pada akses internet, sehingga remaja lebih banyak membuat pilihan mandiri. Pilihan yang dibuat seringkali kurang tepat sehingga secara tidak langsung menyebabkan masalah gizi. Kebiasaan makan yang buruk sering terjadi pada usia remaja karena meraka makan dengan seadanya tanpa mengetahui kebutuhan akan zat gizi terhadap kesehatan (Winarsih, 2018)

Peran guru pembimbing sangat menentukan dalam upaya pencegahan penyalahgunaan Napza di sekolah atau meminimalkan faktor penyebab penyalahgunaan Napza tersebut (Hawari, 2015). Keberadaan dan peran serta guru pembimbing di sekolah sangat diperlukan. Guru bisa bekerjasama dengan tenaga kesehatan untuk memberikan pendidikan kesehatan tentang Napza dan gizi yang seimbang. Salah satu edukasi yang dapat diberikan adalah melalui media sosial. Media sosial efektif digunakan untuk memberikan pendidikan kesehatan karena dapat menambah pengetahuan siswa dan mempengaruhi perilaku dalam mencegah penularan suatu penyakit (Wardani, dkk, 2020).

Mengingat pentingnya Napza dan juga asupan gizi yang berimbang pada remaja dalam mencegah perilaku penyalahgunaan yang terjadi memotivasi peneliti untuk meneliti pengaruh edukasi melalui webinar terhadap tingkat pengetahuan tentang napza dan gizi bagi remaja di Surabaya.

\section{Metode Penelitian}

Penelitian ini adalah quasi experiment dengan rancangan penelitian nonrandomized pretest-postest control group design. Penelitian ini telah mendapatkan persyaratan kelayakan etik dari Komisi Etik Universitas nahdlatul ulama Surabaya pada 28 Juni 2019 dengan nomor 192/EC/KEPK/UNUSA/2019.

Penelitian dilaksanakan di SMP Kartini Sukomanunggal selama satu bulan. Populasi dalam penelitian ini sebanyak 113 siswa dan sampel yang digunakan dalam penelitian ini sebanyak 88 siswa. Kriteria inklusi dalam penelitian ini yaitu siswa yang bersedia menjadi responden. Kriteria eksklusi dalam penelitian ini adalah siswa yang tidak mengikuti webinar. Teknik pengambilan sampel dengan simple random sampling.

Instrumen penelitian yang digunakan adalah lembar kuesioner yang telah dimasukan kedalam google form yang linknya diberikan kepada siswa yang berisi pertanyaan terkait variabel napza dan gizi. Kuesioner sebanyak 25 item pertanyaan untuk masing-maisng variable. Semakin tinggi skor menunjukkan pengetahuan semakin baik. Peneliti melakukan uji coba kuesioner terlebih dahulu pada 30 siswa dan dinyatakan valid untuk digunakan $(\mathrm{r}>0.361)$ dengan hasil cronbach alpha $(0.83)$.

Setelah data terkumpul kemudian diolah langkah selanjutnya data dianalisis, analisis yang digunakan yaitu uji statistik Wilcoxon Signed Ranks Test dengan menggunakan program SPSS versi 23,0 for windows dengan tingkat signifikan $\alpha=0,05$. Jika hasil uji statistik menunjukkan $\mathrm{p}<\alpha 0,05$ maka hipotesis ditolak yang berarti ada pengaruh antara variabel independen dan dependen. 


\section{Hasil dan Pembahasan}

\section{Hasil}

Tabel 1 Karakteristik responden

\begin{tabular}{cccc}
\hline No & Variabel & $\begin{array}{c}\text { Jumlah } \\
(\mathbf{n = 8 8})\end{array}$ & $\begin{array}{c}\text { Prosentase } \\
(\mathbf{\%})\end{array}$ \\
\hline 1. & Usia (tahun) & & \\
& $11-14$ & 77 & 87,5 \\
2. & $15-17$ & 11 & 12,5 \\
\hline & Jenis kelamin & & \\
\hline & Laki-laki & 71 & 80,7 \\
& Perempuan & 17 & 19,3 \\
\hline
\end{tabular}

Sumber : Data primer, (2021)

Berdasarkan tabel 1 dapat dilihat bahwa responden mayoritas remaja awal berusia 11-14 tahun (87,5\%), dengan jenis kelamin mayoritas laki-laki $(80,7 \%)$.

Tabel 2 Pengaruh edukasi melalui webinar terhadap tingkat pengetahuan tentang Napza

\begin{tabular}{lccc}
\hline Pengetahuan tentang Napza & $\mathrm{n}$ & Rerata nilai \pm S.b & $p$ value \\
\hline Sebelum edukasi & 44 & $5,99 \pm 1,31$ & 0,001 \\
Setelah edukasi & 44 & $6,4 \pm 1,1$ & \\
\hline
\end{tabular}

Sumber : Data primer, (2021)

Berdasarkan tabel diatas menunjukkan bahwa terdapat pengaruh edukasi melalui webinar. Hasil uji Wilcoxon didapatkan $p$ value $0,001(\mathrm{p}<0,05)$ maka dapat disimpulkan bahwa Ha diterima, artinya ada perubahan rerata pengetahuan signifikan pengetahuan responden mengenai Napza sebelum dan sesudah mengikuti webinar. Hal ini menunjukkan bahwa webinar memiliki pengaruh dalam peningkatan pengetahuan remaja mengenai Napza.

Tabel 3 Pengaruh edukasi melalui webinar terhadap tingkat pengetahuan tentang gizi

\begin{tabular}{lccc}
\hline Pengetahuan tentang Gizi & $\mathrm{n}$ & Rerata nilai \pm S.b & $p$ value \\
\hline Sebelum edukasi & 44 & $6,77 \pm 1,43$ & 0,000 \\
Setelah edukasi & & $7,24 \pm 1,1$ & \\
\hline
\end{tabular}

Berdasarkan tabel 3 dapat dilihat bahwa pengaruh edukasi melalui webinar. Hasil uji Wilcoxon didapatkan $p$ value $0,000(\mathrm{p}<0,05)$ maka dapat disimpulkan bahwa Ha diterima, artinya ada perubahan rerata pengetahuan signifikan pengetahuan responden mengenai gizi sebelum dan sesudah mengikuti webinar. Hal ini menunjukkan bahwa webinar memiliki pengaruh dalam peningkatan pengetahuan remaja mengenai gizi. 


\section{Pembahasan}

\section{Pengaruh edukasi melalui webinar terhadap tingkat pengetahuan tentang NAPZA}

Hasil penelitian yang telah dilakukan peneliti menunjukan ada pengaruh edukasi melalui webinar terhadap tingkat pengetahuan tentang Napza bagi remaja.

Audiovisual dapat membantu remaja dalam menambah pengetahuan dan wawasannya karena pada media audiovisual lebih menarik untuk dilihat dan didengar karena disajikan dalam 3 dimensi sehingga informasi yang disampaikan bisa lebih diterima oelh remaja termasuk di dalamnya adalah informasi tentang Napza. Salah satu audiovisual yang sering digunakan pada saat pandemi seperti saat ini adalah webinar.

Hal ini sejalan dengan penelitian yang dilakukan oleh Wardani, dkk., (2020), yang mengatakan bahwa didapatkan $\mathrm{p}=0.001$, artinya ada perbedaan yang signifikan antara pengetahuan masyarakat sebelum dengan setelah diberikan pendidikan kesehatan menggunakan webinar. Hasil penelitian ini tidak sejalan dengan penelitian Kasman (2017) yang menyebutkan bahwa tidak ada pengaruh penggunaan media video terhadap pengetahuan siswa SDN 78 Sabrang Lor Mojosongo tentang bahaya merokok.

Menurut Notoatmodjo (2017) dengan pendidikan yang cukup baik terjadi proses pertumbuhan, perkembangan dan perubahan kearah yang lebih dewasa, lebih baik dan matang pada individu, kelompok ataupun masyarakat. Individu dengan pendidikan SMP seharusnya sudah dapat memahami informasi tentang NAPZA.

Permasalahan penyalahgunaan narkoba memerlukan pemecahan bersama, melibatkan seluruh pemangku kepentingan dan seluruh komponen masyarakat, oleh karena merupakan ancaman besar bagi bangsa Indonesia, khususnya generasi muda, Karena disamping dampak negatif bagi penyalahguna juga menyebarkan penyakit seperti HIV/AIDS dan virus hepatitis melalui penggunaan jarum suntik yang pada akhirnya menyebabkan kematian jutaan jiwa, sehingga merugikan bangsa. Pentingnya edukasi secara berkala dilakukan guna mencegah dampak pada remaja dengan pengetahuan yang baik diharapkan dapat menekan masalah penyalahgunaan Napza.

\section{Pengaruh edukasi melalui webinar terhadap tingkat pengetahuan tentang gizi}

Hasil penelitian yang telah dilakukan peneliti menunjukan ada pengaruh edukasi melalui webinar terhadap tingkat pengetahuan tentang gizi bagi remaja.

Informasi yang diberikan kepada responden dengan menggunakan media audiovisual dan video dapat dipahami karena setiap responden dapat dengan mudah mengamatinya saat melihat gambar atau mendengarkan suara. Dalam hal ini dianggap efisien dan praktis, serta video yang mudah dipahami dan dapat diulang, secara efektif mengubah perspektif target intervensi (Igiany, et al., 2016).

Hal ini sejalan dengan penelitian yang dilakukan oleh Wardani, dkk., (2021), yang mana penelitian tentang telemedicine yang juga merupakan pemberian edukasi secara online selain webinar, dimana dalam penelitiannya di dapatkan hasil bahwa telemedicine di masa pandemi menjadi solusi alternatif yang ditawarkan untuk tetap melakukan konsultasi kesehatan secara daring baik dengan dokter, perawat, ahli gizi maupun tim kesehatan yang lain.

Menurut Mulyani, et al., (2020), media edukasi online dapat memberikan dampak terhadap peningkatan pemahaman dan perubahan perilaku. Informasi yang diberikan kepada responden dengan menggunakan media audio visual atau video mudah dimengerti karena setiap siswa akan mudah memperhatikan apabila ada gambar suara yang dapat dilihat dan didengar. Video lebih bersifat mudah dipahami dan bisa di tayangankan 
berulang kali karena dianggap efisien dan praktis dan juga efektif untuk mengubah pandangan sasaran yang akan di intervensi (Igiany, et al., 2016).

Usia remaja adalah usia pertumbuhan, ketika banyak organ tubuh berkembang pesat dan menentukan kesehatan seseorang ketika dewasa. Karena itu, kebutuhan gizi remaja perlu dipenuhi dengan baik. Edukasi melalui webinar diharapkan akan mengurangi angka remaja yang kekurangan zat besi (anemia), kurang tinggi badan (stunting), kurang energi kronis (kurus), dan kegemukan. Remaja juga diharapkan dapat mengubah kebiasaan mengkonsumsi makanan yang bergizi seimbang serta membiasakan hidup sehat.

\section{Kesimpulan}

Edukasi melalui webinar efektif dilakukan guna meningkatkan pengetahuan tentang Napza dan gizi bagi remaja.

Perlu dilakukan edukasi secara berkala oleh petugas kesehatan bekerja sama dengan pihak sekolah menggunakan media zoom secara berkala guna meningkatkan pengetahuan dan sikap siswa terkait Napza dan gizi pada remaja .

\section{Referensi}

Badan Narkotika Nasional Surabaya. (2015). Penjangkauan Bidang Rehabilitasi. Surabaya : Deputi Bidang Pencegahan Direktorat Diserminasi Informasi.

Badan Narkotika Nasional Jawa Timur. (2016). Penjangkauan Bidang Rehabilitasi. Surabaya : Deputi Bidang Pencegahan Direktorat Diserminasi Informasi.

Badan Narkotika Republik Indonesi. 2016. Mengenai Penyalahgunaan Narkoba. Buku 2 A Untuk Remaja Atau Anak Muda. Jakarta : Deputi Bidang Pencegahan Direktorat Diserminasi Informasi.

Hawari, D. (2015). Penyalahgunaan dan Ketergantungan Napza. Jakarta : Balai Penerbit FKUI.

Igiany, P. D., Sudargo, T., \& Widyatama, R. (2016). Efektivitas penggunaan video dan buku bergambar dalam meningkatkan pengetahuan, sikap, dan keterampilan ibu mencuci tangan memakai sabun. Berita Kedokteran Masyarakat, 32(3), 89-94.

Iskandar, Lutfi. 2017. Penyuluhan Hukum Pencegahan Penyalahgunaan Narkoba oleh Kemenkumham Kantor Wilayah Kalimantan Selatan. Skripsi. Jurusan Hukum Tata Negara. Fakultas Syariah dan Ekonomi Islam IAIN Antasari Banjarmasin.

Kasman, K., Noorhidayah, N., \& Persada, K. B. (2017). Studi Eksperimen Penggunaan Media Leaflet Dan Video Bahaya Merokok Pada Remaja. Jurnal Publikasi Kesehatan Masyarakat Indonesia, 4(2), 10-14. https://doi.org/10.20527/jpkmi.v4i2.3842

Kementerian Kesehatan RI. 2018. Hasil Riset Kesehatan Dasar (Riskesdas) 2018. Jakarta: Badan Penelitian dan Pengembangan Kesehatan Kementerian RI.

Mulyani, E. Y., Ummanah, N. A., \& Elvandari, M. (2020). Peningkatan Pengetahuan Mahasiswa Melalui Edukasi Online Gizi dan Imunitas Saat Pandemic Covid-19. $1(1), 70-78$.

Notoatmodjo. (2017). Promosi Kesehatan dan Ilmu Perilaku. Jakarta: Rineka Cipta.

Setiawan, H,S. (2015). Faktor-faktor Penyalahgunaan Narkoba Pada Siswa Sekolah Lanjutan Tingkat Atas. Tesis Universitas Indonesia. 
UNODC. (2016). World Drug Report. New York: UNODC.

Wardani, E., Bistara, D., \& Setiyowati, E. (2020). The Influence of Social Media About Covid-19 on Handwashing Behavior, Mask Wearing and Physical Distancing of Indonesian Students. STRADA Jurnal Ilmiah Kesehatan,9(2), 1338-1345. https://doi.org/10.30994/sjik.v9i2.459

Wardani, EM, Bistara, DN, Septianingrum, S. (2021). Promosi Kesehatan Pencegahan Penularan Infeksi Covid-19 Pada Masyarakat Melalui Webinar Series. Dedication : Jurnal Pengabdian Kepada Masyarakat, 5(1), 71-76. https://doi.org/10.31537/dedication.v5i1.441

Wardani, E. M. ., \& Nugroho , R. F. . (2021). Implementation of Telemedicine on Knowledge of 7M Health Protocols, Vaccines and Nutrition. JoPHIN: Journal of Public Health and Industrial Nutrition, 1(1), 15-21. Retrieved from https://journal.tritunas.ac.id/index.php/JoPHIN/article/view/19Winarsih. (2018). Pengantar ilmu gizi dalam kebidanan. Yogyakarta: Pustaka Baru. 